\title{
External knowledge search, absorptive capacity and radical innovation in high-technology firms
}

\section{Luisa Flor $^{\mathrm{a}, *}$ \\ mflor@uji.es}

Sarah Y. Cooper

Sarah.Cooper@ed.ac.uk

María J. Oltra

oltra@uji.es

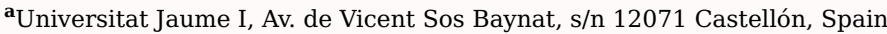

buniversity of Edinburgh Business School, University of Edinburgh, Edinburgh, UK

${ }^{*}$ Corresponding author.

Abstract

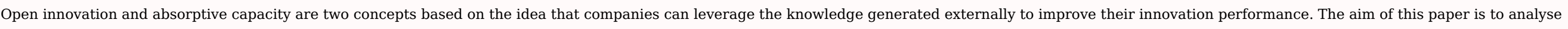

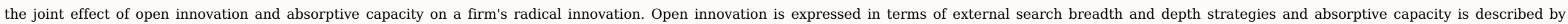

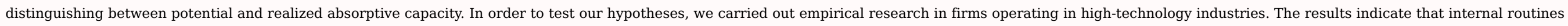

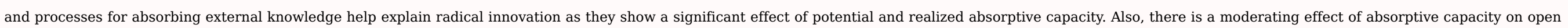

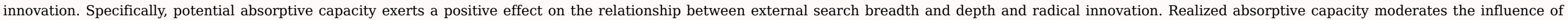
external search breadth. These findings confirm the complementary nature of absorptive capacity and open innovation search strategies on radical innovation.

Keywords: External knowledge search; Absorptive capacity; Radical innovation

\section{Introduction}

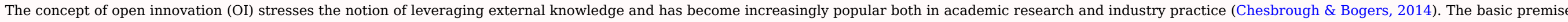

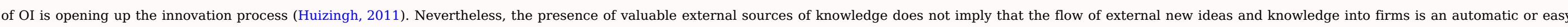

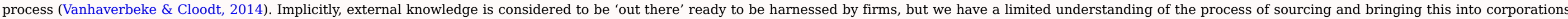
(Dahlander \& Gann, 2010). The ability to exploit external knowledge is, thus, a critical component of innovative capabilities (Cohen \& Levinthal, 1990).

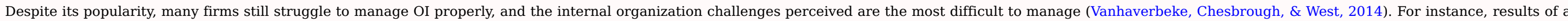

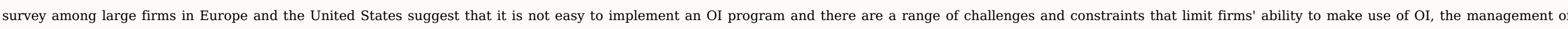

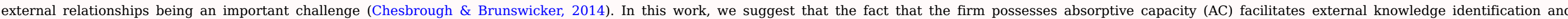

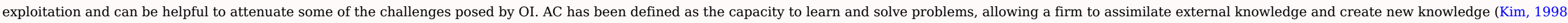

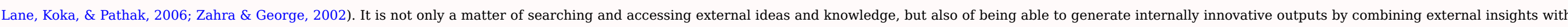

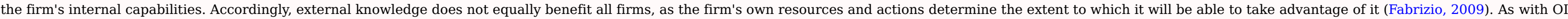

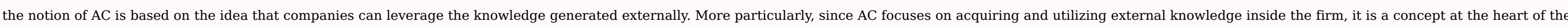
outside-in dimension of OI (Vanhaverbeke \& Cloodt, 2014). 


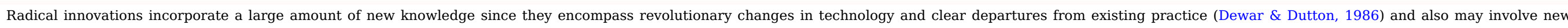

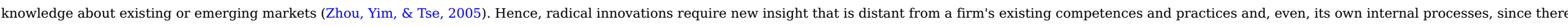

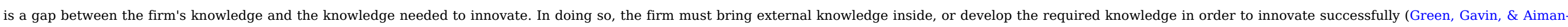

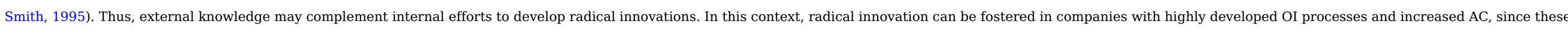

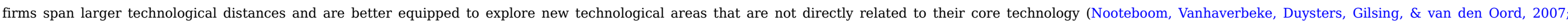
Vanhaverbeke \& Cloodt, 2014).

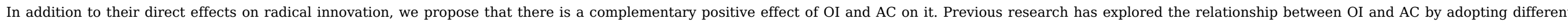

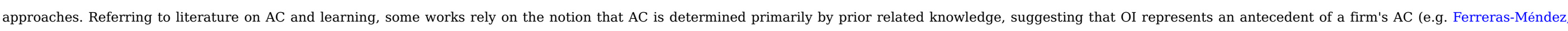

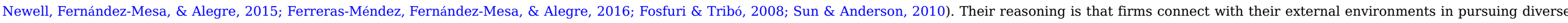

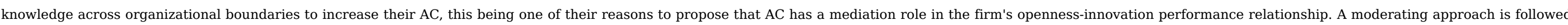

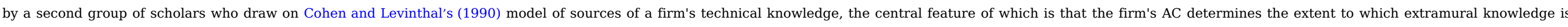

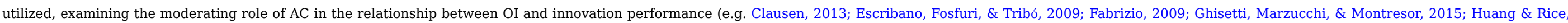

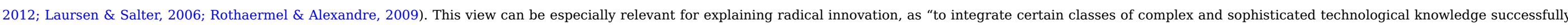

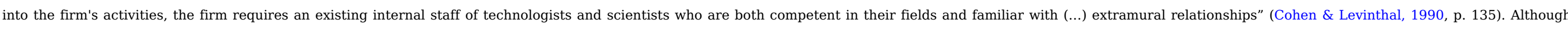

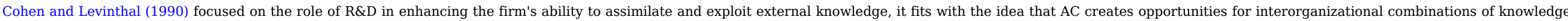

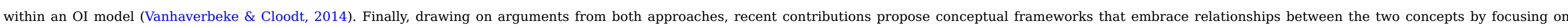
different types of OI and the components of AC (e.g., Kim, Kim, \& Foss, 2016; Xia \& Roper, 2016)

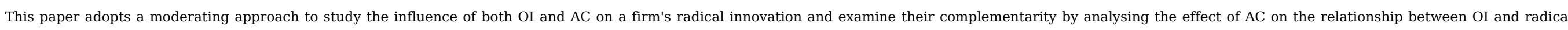

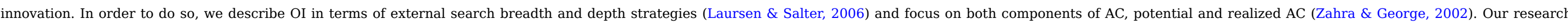

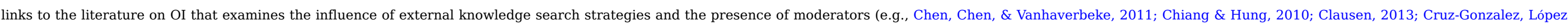

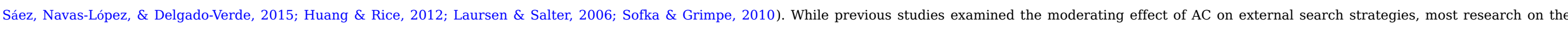

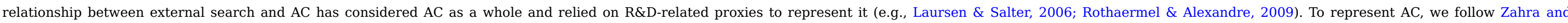

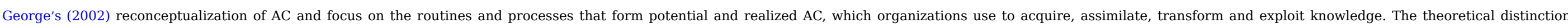

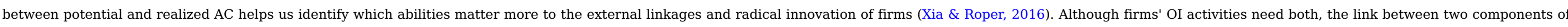

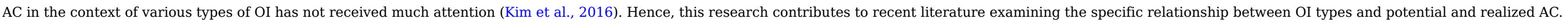

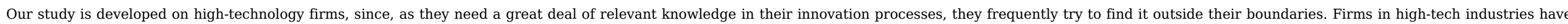

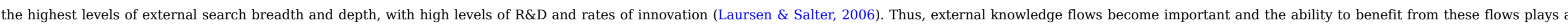

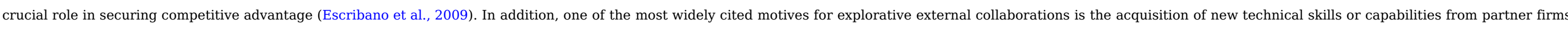
(Xia \& Roper, 2016).

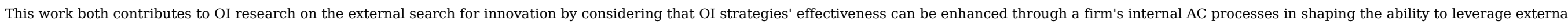

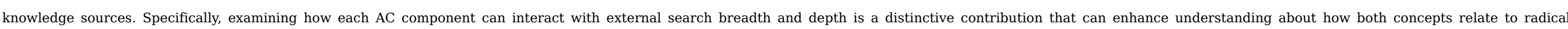
innovation.

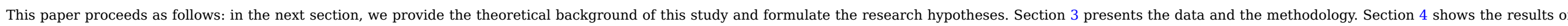
the data analysis and Section 5 discusses the results. Section 6 summarizes key conclusions, implications and limitations of the work.

\section{Literature review and hypotheses development}




\subsection{Radical innovation}

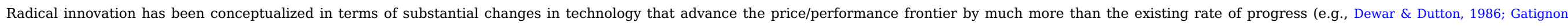

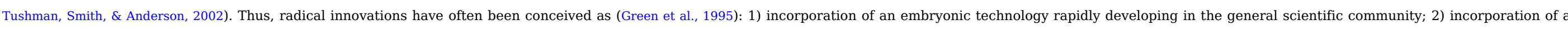

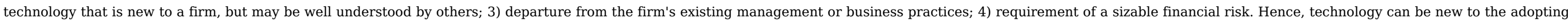

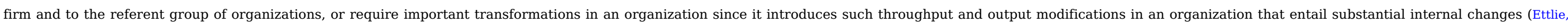

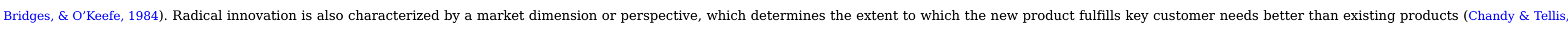

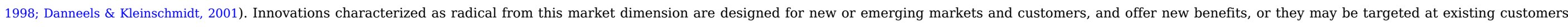
and offer radically different benefits (Zhou et al., 2005).

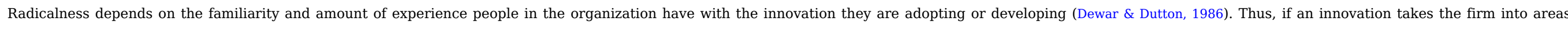

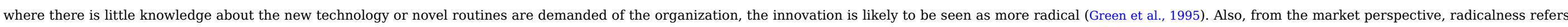

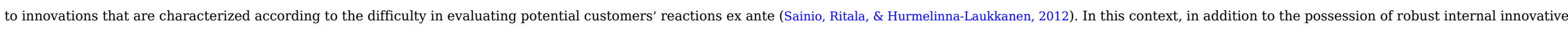
capabilities, knowledge on insights and expertise developed externally can be determinants in developing successful radical innovations.

\subsection{External knowledge search and radical innovation}

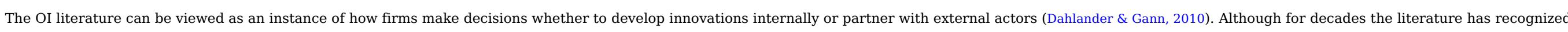

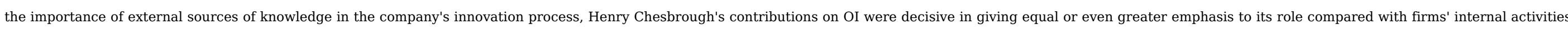

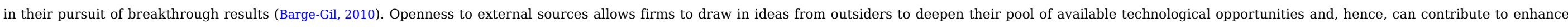
their innovation results (Laursen \& Salter, 2006).

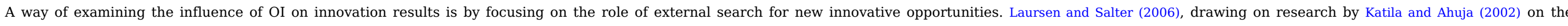

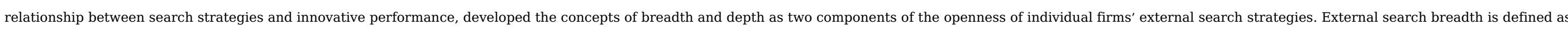

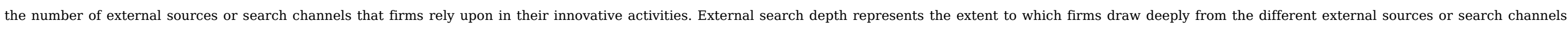
Searching widely and deeply across a variety of channels can provide ideas and resources that help firms gain and exploit innovative opportunities (Laursen \& Salter, 2006).

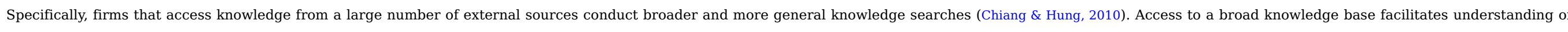

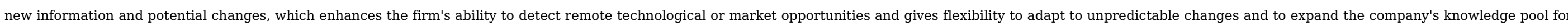

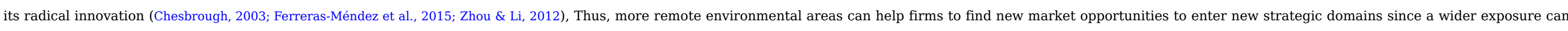

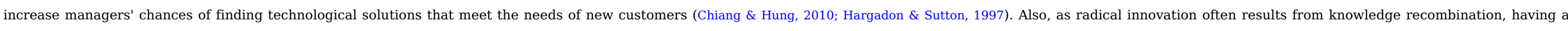

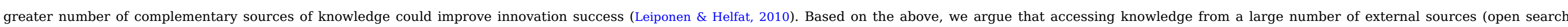
breadth) will positively relate to the company's radical innovation, leading us to propose the following:

H1 Open search breadth will exert a positive effect on a firm's radical innovation.

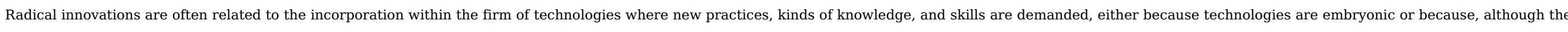

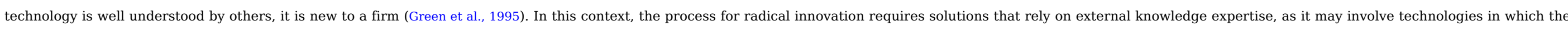

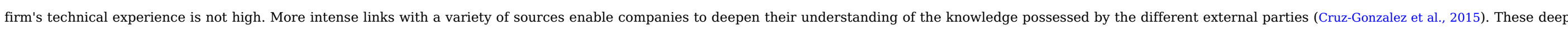

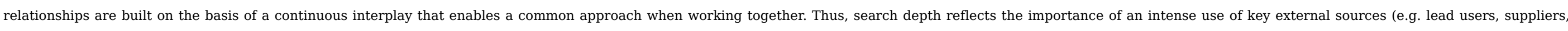

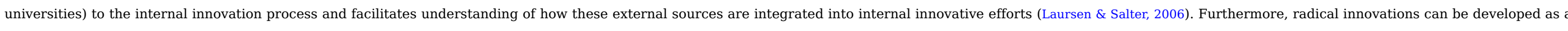

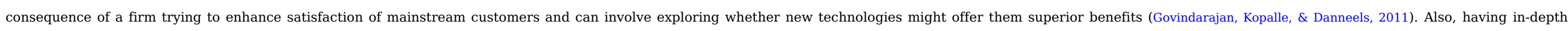




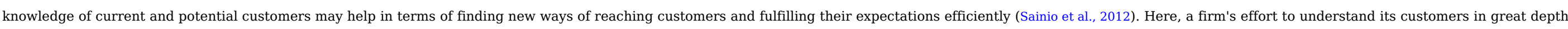

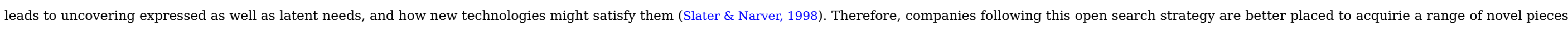

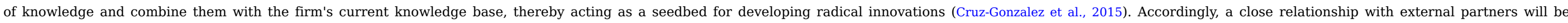
fundamental in providing the required technical or market knowledge that complements the internal efforts for effective radical innovation. Based on the above, we propose that:

H2 Open search depth will exert a positive effect on a firm's radical innovation.

\subsection{Absorptive capacity and radical innovation}

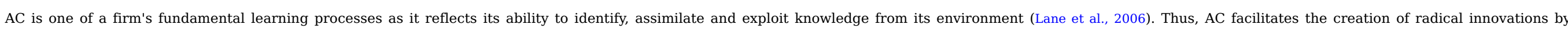
enabling the exchange of existing knowledge and learning, and combining it with new sources of knowledge (Ritala \& Hurmelinna-Laukkanen, 2013).

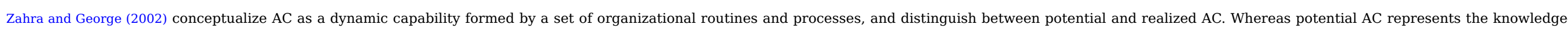
seeking capacities a firm has developed, but which may or may not be used to produce innovations, realized AC represents its ability to develop products and services based on this stock of knowledge.

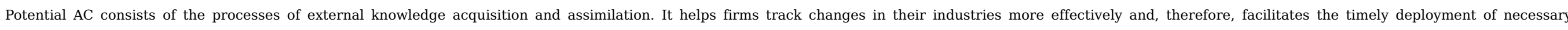

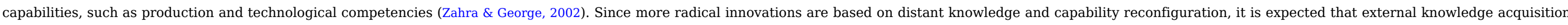

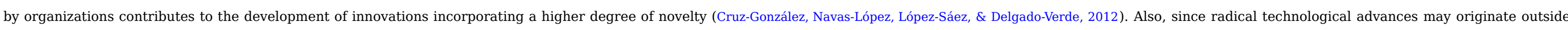

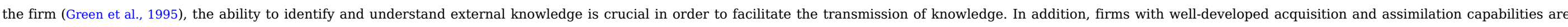

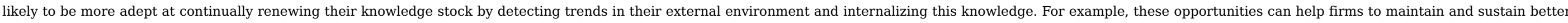

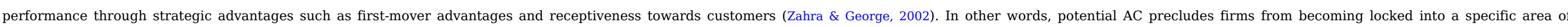

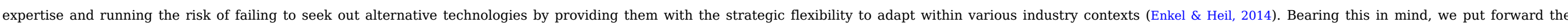
following hypothesis:

H3 Potential AC will exert a positive effect on a firm's radical innovation.

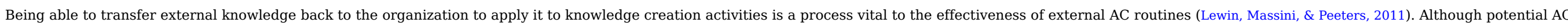

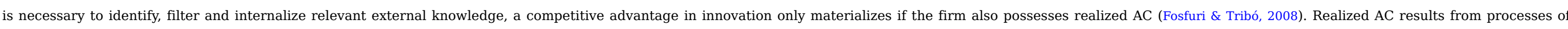

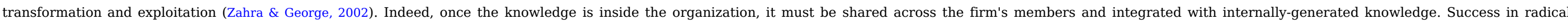

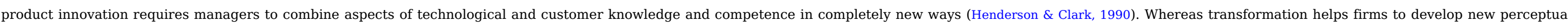

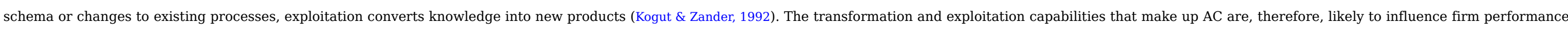
through product and process innovation (Zahra \& George, 2002). Thus, we propose the following hypothesis:

H4 Realized AC will exert a positive effect on a firm's radical innovation.

\subsection{External knowledge search, absorptive capacity, and radical innovation}

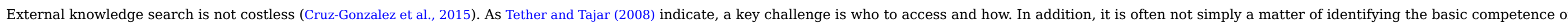

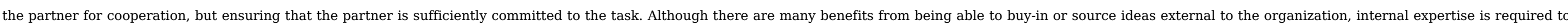

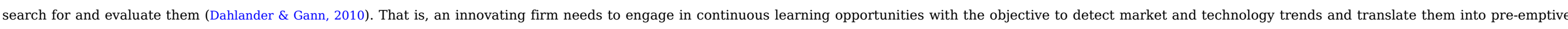

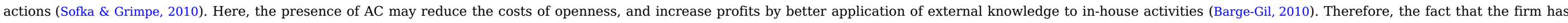
developed AC can be a key determinant in fostering the positive effects of a broad and intense use of external sources.

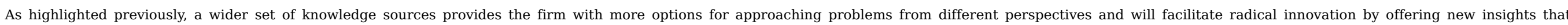




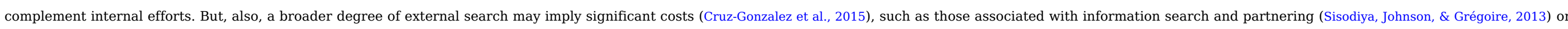
with the range of management skills required to deal with diverse external sources (Faems, de Visser, Andries, \& Van Looy, 2010).

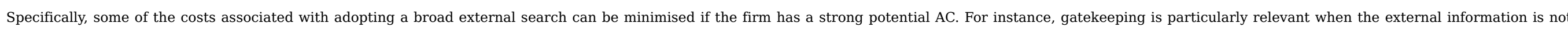

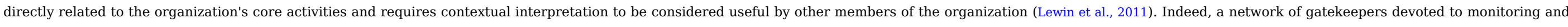

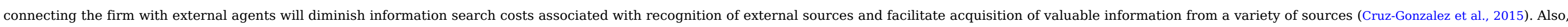

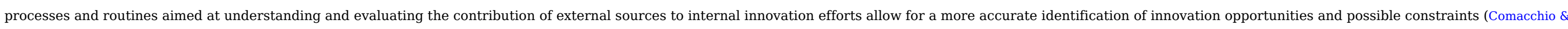
Bonesso, 2011, pp. 15-17). Thus, the fact that there are internal capabilities related to where and how to search, i. e, potential AC, will make the breadth search strategy more effective.

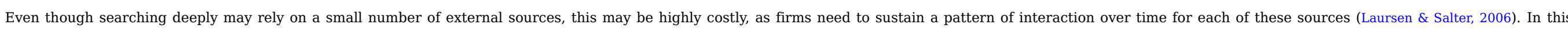

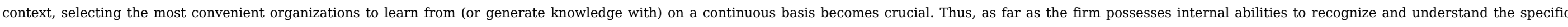

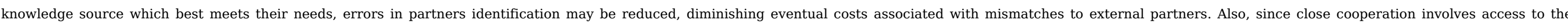

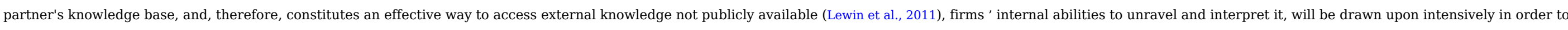
obtain valuable knowledge for radical innovation. Based on the above, we propose the following:

H5 Potential AC will exert a positive effect on the relationship between open search breadth and depth and radical innovation.

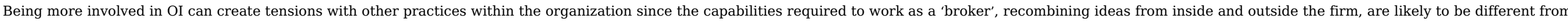

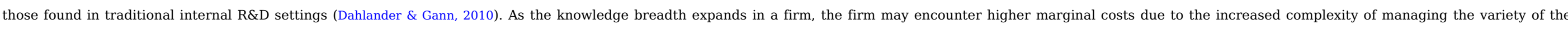

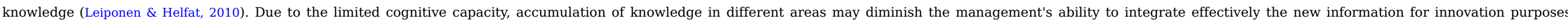

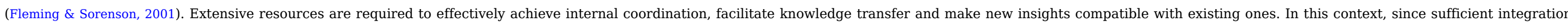

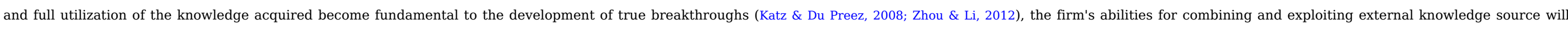
enhance the benefits of external knowledge breadth search strategies in its internal innovation process.

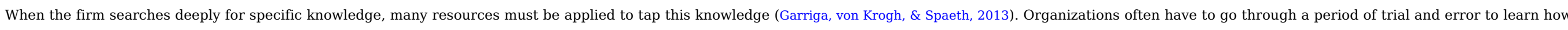

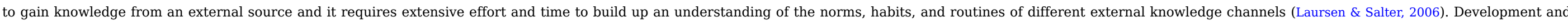

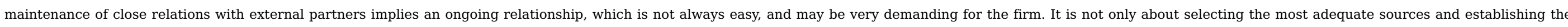

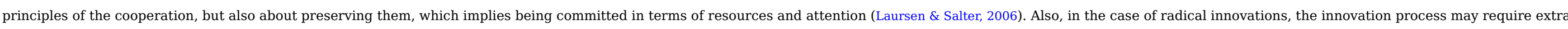

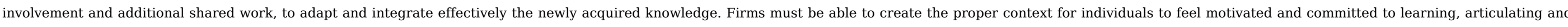

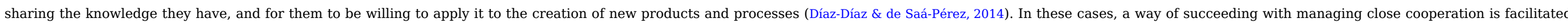

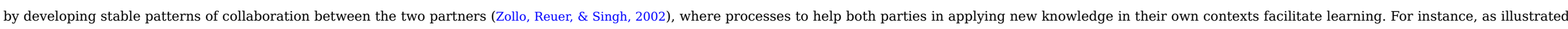

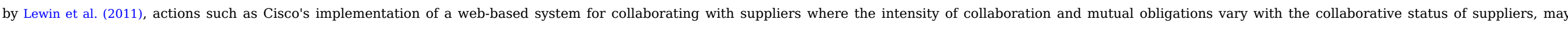

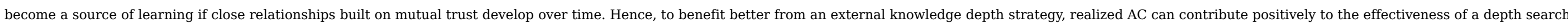
strategy. Accordingly, the above considerations let us suggest that:

H6 Realized AC will exert a positive effect on the relationship between open search breadth and depth and radical innovation.

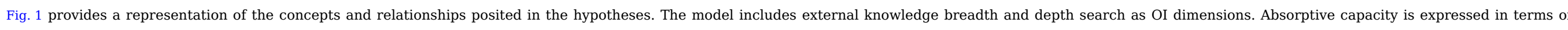

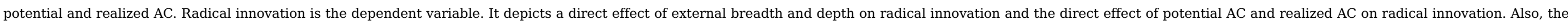
moderating effect of AC components is represented. 


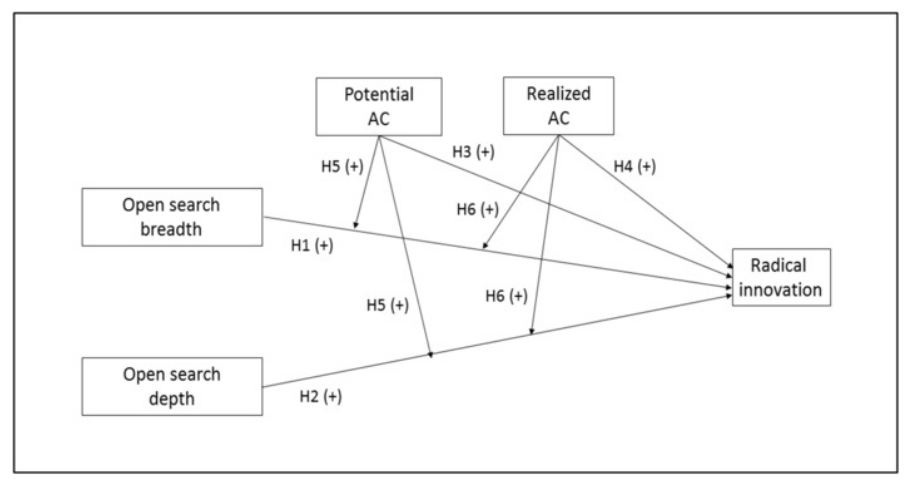

Fig. 1 The conceptual model.

\section{alt-text: Fig. 1}

\section{Methodology}

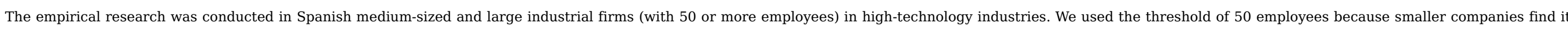

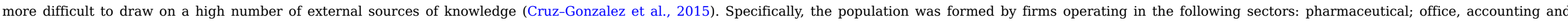

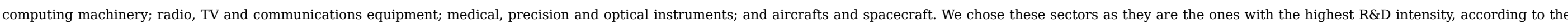

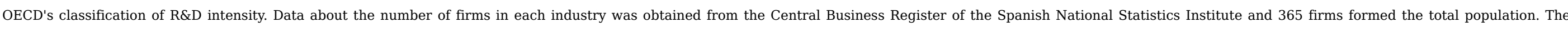

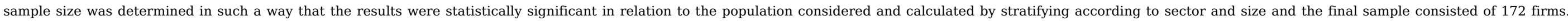
Table 1 shows the sample composition by sectors.

\section{Table 1 Sample composition.}

alt-text: Table 1

\section{Sector}

Pharmaceuticals

Office, accounting and computing machinery

Radio, TV and communications equipment

Medical, precision and optical instruments

Aircrafts and spacecraft

Total

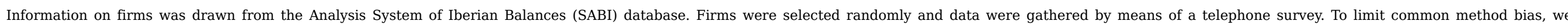

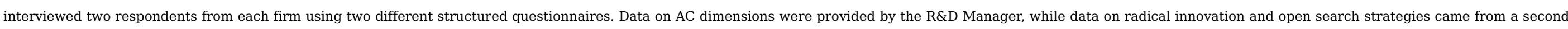

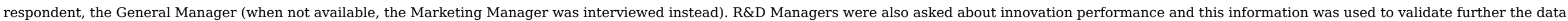

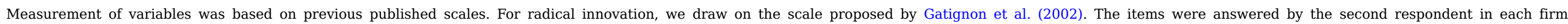

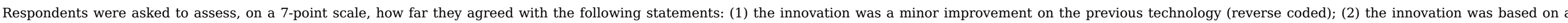

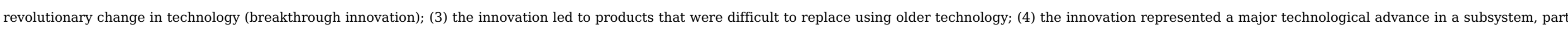




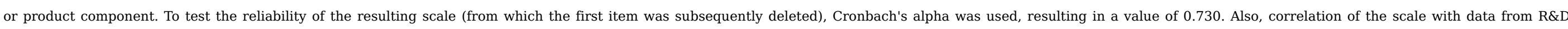
managers on the same scale $(\rho=0.629, \mathrm{p}<0.001)$ contributed to give additional support to its validity.

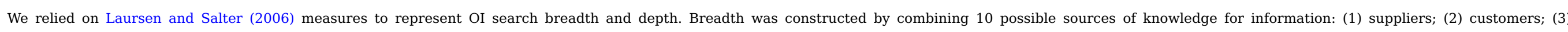

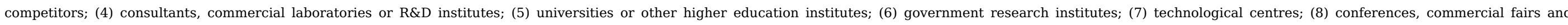

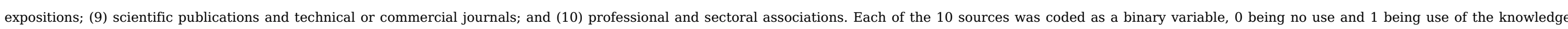

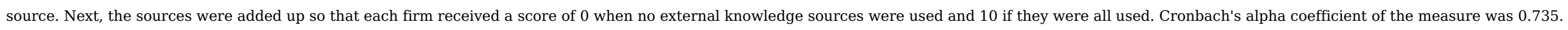

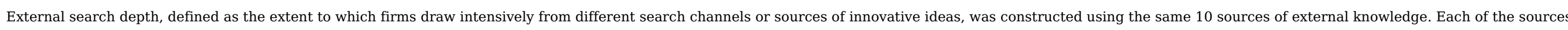

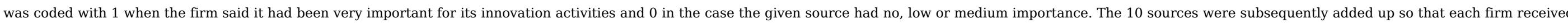

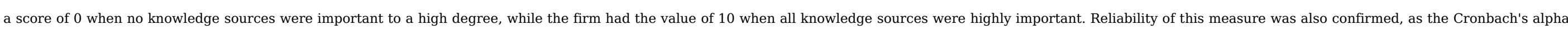
coefficient was 0.725 .

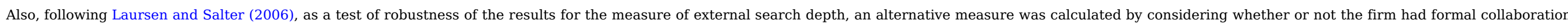

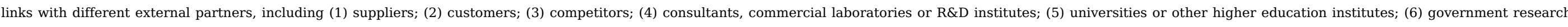

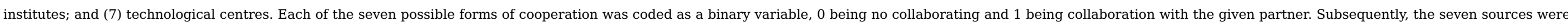

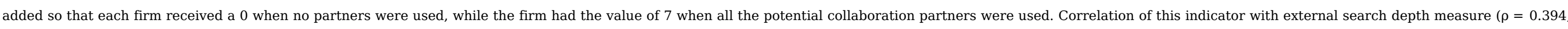
$p<0.01$ ) confirmed the robustness of the measure.

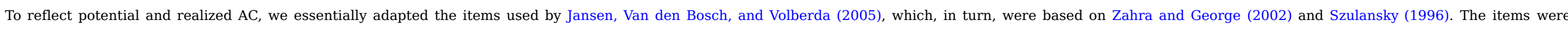

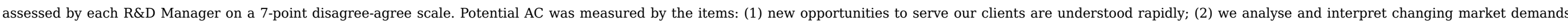

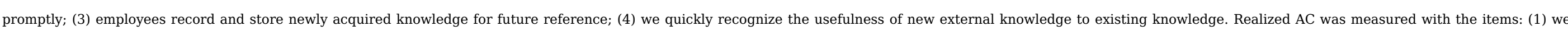

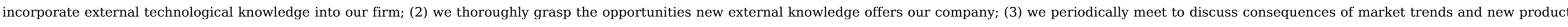

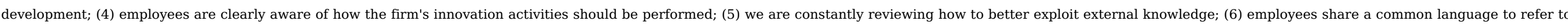

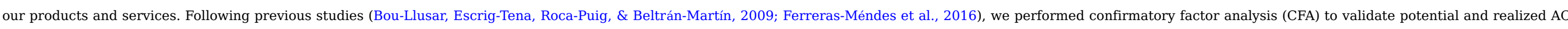

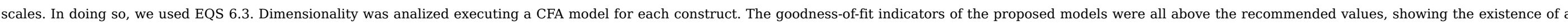

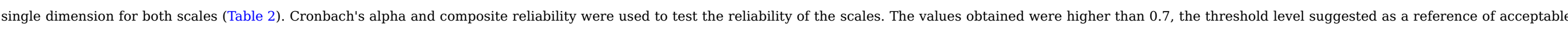

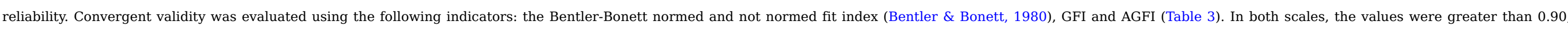

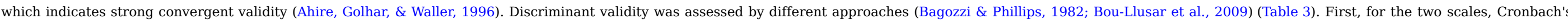

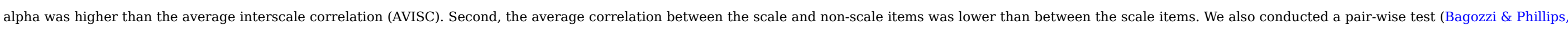

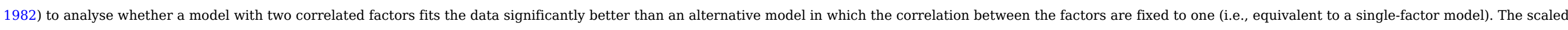
chi-square difference values were found to be statistically significant at $5 \%$ level (S-B scale difference $=22.15$; d. f. $=1$ ) (Satorra \& Bentler, 2001), rejecting thus the perfectly correlated two-factor model.

Table 2 AC scales dimensionality and reliability analysis.

\begin{tabular}{|c|c|c|c|c|c|c|}
\hline & \multicolumn{4}{|c|}{ Unidimensionality } & \multicolumn{2}{|r|}{ Reliability } \\
\hline & $\begin{array}{l}\text { Satorra-Bentler } \\
\text { Chi-square }\end{array}$ & $\mathrm{df}$ & $p$-Value & Comparative Factor Index (CFI) & Cronbach's $\alpha$ & Composite reliability \\
\hline Potential AC & 4.951 & 2 & 0.084 & 0.976 & 0.748 & 0.866 \\
\hline Realized AC & 14.844 & 14 & 0.388 & 0.996 & 0.736 & 0.742 \\
\hline
\end{tabular}


Table 3 AC scales convergent and discriminant validity analysis.

alt-text: Table 3

\begin{tabular}{|c|c|c|c|c|c|c|c|}
\hline & \multicolumn{4}{|c|}{ Convergent validity } & \multicolumn{3}{|c|}{ Discriminant validity } \\
\hline & \multirow[t]{2}{*}{ BBNFI } & \multirow[t]{2}{*}{ BB-NNFI } & \multirow[t]{2}{*}{ GFI } & \multirow[t]{2}{*}{ AGFI } & \multirow[t]{2}{*}{ Average interscale correlation (AVISC) } & \multicolumn{2}{|c|}{ Average item-to-scale correlations with } \\
\hline & & & & & & Scale items & Non-scale items \\
\hline Potential AC & 0.961 & 0.927 & 0.985 & 0.924 & \multirow[t]{2}{*}{0.260} & 0.758 & 0.369 \\
\hline Realized AC & 0.940 & 0.994 & 0.973 & 0.947 & & 0.714 & 0.395 \\
\hline
\end{tabular}

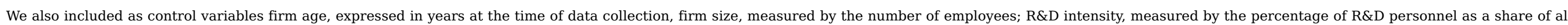

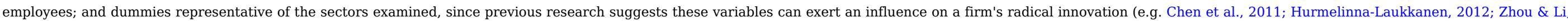
2012). Logarithmic transformations were used in age, size and R\&D intensity measures.

\section{Results}

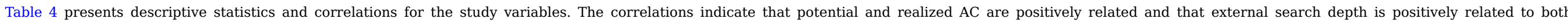

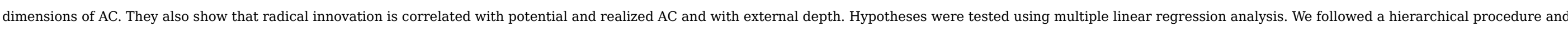

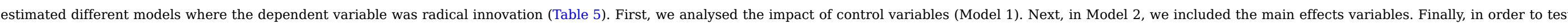

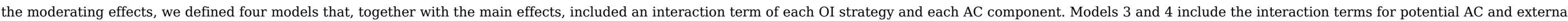

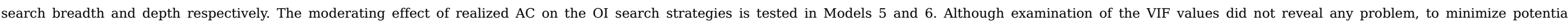
multicollinearity, we standardized the variables for the interaction terms prior to creating the respective cross products.

Table 4 Means, standard deviations and correlations.

alt-text: Table 4

\begin{tabular}{|c|c|c|c|c|c|c|c|c|c|}
\hline & Mean & S.D. & 1 & 2 & 3 & 4 & 5 & 6 & 7 \\
\hline 1. Radical innovation & 4.5349 & 0.7877 & & & & & & & \\
\hline 2. Age & 30.2038 & 21.7769 & -0.012 & & & & & & \\
\hline 3. Size & 262.89 & 354.848 & 0.062 & 0.102 & & & & & \\
\hline 4. $R \& D$ intensity & 7.7708 & 7.9649 & -0.057 & -0.119 & $-0.181^{a}$ & & & & \\
\hline 5. Search breadth & 9.7326 & 0.8436 & 0.005 & -0.105 & $0.191^{\mathrm{a}}$ & $0.217^{b}$ & & & \\
\hline 6. Search depth & 3.5407 & 2.5139 & $0.165^{\mathrm{a}}$ & 0.026 & $0.185^{\mathrm{a}}$ & 0.028 & 0.093 & & \\
\hline 7. Potential AC & 4.4655 & 0.8994 & $0.479^{\mathrm{b}}$ & -0.126 & -0.022 & -0.086 & -0.077 & $0.205^{b}$ & \\
\hline 8. Realized AC & 4.8735 & 0.5891 & $0.406^{b}$ & -0.004 & 0.081 & 0.015 & 0.095 & $0.174^{\mathrm{a}}$ & $0.557 \mathrm{~b}$ \\
\hline
\end{tabular}

Variables 2, 3 and 4 describe actual values for descriptive statistics. Logarithmic transformations of these variables were used in regression analysis.

${ }^{\text {a }}$ Correlation significant at the 0.1 level.

b Correlation significant at the 0.05 level. 
Table 5 Results of regression analysis. Standardizsed coefficients ( $\beta$ ).

\begin{tabular}{|c|c|c|c|c|c|c|c|c|c|c|c|c|c|}
\hline & \multicolumn{2}{|c|}{$\begin{array}{c}\text { Model } \\
1\end{array}$} & \multicolumn{3}{|c|}{$\begin{array}{c}\text { Model } \\
2\end{array}$} & \multicolumn{2}{|c|}{$\begin{array}{c}\text { Model } \\
3\end{array}$} & \multicolumn{2}{|c|}{$\begin{array}{c}\text { Model } \\
4\end{array}$} & \multicolumn{2}{|c|}{$\begin{array}{c}\text { Model } \\
5\end{array}$} & \multicolumn{2}{|c|}{$\begin{array}{c}\text { Model } \\
6\end{array}$} \\
\hline & Beta & $t$ & Beta & $t$ & VIF & Beta & $t$ & Beta & $t$ & Beta & $t$ & Beta & $t$ \\
\hline Age & -0.060 & $-0,693$ & -0.006 & -0.077 & 1.379 & 0.008 & 0.099 & 0.005 & 0.063 & 0.008 & 0.103 & -0.002 & -0.031 \\
\hline Size & 0.079 & 0.996 & 0.065 & 0.898 & 1.212 & 0.074 & 1.056 & 0.088 & 1.230 & 0.064 & 0.897 & 0.057 & 0.792 \\
\hline $\mathrm{R} \& \mathrm{D}$ intensity & -0.044 & -0.559 & -0.024 & -0.341 & 1.187 & -0.023 & -0.349 & 0.002 & 0.035 & -0.030 & -0.424 & -0.007 & -0.095 \\
\hline Pharmaceutical & -0.01 & -0.075 & 0.009 & 0.079 & 3.302 & 0.022 & 0.237 & 0.033 & 0.283 & 0.031 & 0.265 & 0.012 & 0.102 \\
\hline Office and computing machinery & $0206^{b}$ & 2.193 & $0.164^{\mathrm{a}}$ & 1.965 & 1.624 & $0.160^{\mathrm{a}}$ & 2.232 & $0.171^{\mathrm{b}}$ & 2.078 & $0.164^{\mathrm{b}}$ & 1.982 & $0.162^{\mathrm{a}}$ & 1.958 \\
\hline TV and communications equipment & 0.194 & 1.641 & $0.222^{\mathrm{b}}$ & 2.118 & 2.574 & $0.242^{\mathrm{b}}$ & 2.399 & $0.249^{b}$ & 2.388 & $0.255^{b}$ & 2.415 & $0.242^{\mathrm{b}}$ & 2.296 \\
\hline Medical and precision instruments & 0.045 & 0.360 & 0.086 & 0.768 & 2.918 & 0.113 & 1.088 & 0.098 & 0.891 & 0.119 & 1.057 & 0.089 & 0.802 \\
\hline Search breadth & & & 0.001 & 0.015 & 1.175 & -0.016 & -0.232 & -0.004 & -0.057 & 0.043 & 0.581 & 0.019 & 0.269 \\
\hline Search depth & & & 0.032 & 0.460 & 1.139 & 0.026 & 0.376 & -0.013 & -0.186 & 0.030 & 0.438 & 0.005 & 0.072 \\
\hline Potential AC & & & $0.304^{\mathrm{c}}$ & 3.600 & 1.664 & $0.295^{c}$ & 3.598 & $0.314^{\mathrm{c}}$ & 3.764 & $0.311^{\mathrm{c}}$ & 3.713 & $0.298^{c}$ & 3.550 \\
\hline Realized AC & & & $0.252^{\mathrm{c}}$ & 3.026 & 1.624 & $0.316^{c}$ & 3.669 & $0.240^{\mathrm{c}}$ & 2.912 & $0.301^{\mathrm{c}}$ & 3.469 & $0.257^{\mathrm{c}}$ & 3.100 \\
\hline Potential AC ${ }^{\star}$ search breadth & & & & & & $0.158^{\mathrm{b}}$ & 2.250 & & & & & & \\
\hline Potential AC ${ }^{\nexists}$ search depth & & & & & & & & $0.156^{b}$ & 2.250 & & & & \\
\hline Realized $\mathrm{AC}^{\star}$ search breadth & & & & & & & & & & $0.141^{\mathrm{a}}$ & 1.867 & & \\
\hline Realized $\mathrm{AC}^{\star}$ search depth & & & & & & & & & & & & 0.107 & 0.518 \\
\hline $\mathrm{R}^{2}$ & 0.074 & & 0.317 & & & 0.338 & & 0.338 & & 0.331 & & 0.326 & \\
\hline Adj. $R^{2}$ & 0.034 & & 0.270 & & & 0.288 & & 0.288 & & 0.281 & & 0.276 & \\
\hline Change $\mathrm{R}^{2}$ & & & 0.243 & & & 0.021 & & 0.021 & & 0.015 & & 0.010 & \\
\hline$F$ & $1.856^{\mathrm{a}}$ & & $6.738^{\mathrm{c}}$ & & & $6.752^{\mathrm{c}}$ & & $6.756^{\mathrm{c}}$ & & $6.563^{\mathrm{c}}$ & & $6.419^{c}$ & \\
\hline
\end{tabular}

a The relationship is significant at the 0.1 level.

b Therelationship is significant at the 0.05 level.

c The relationship is significant at the 0.001 level.

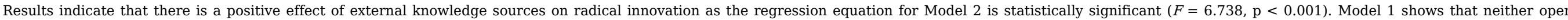

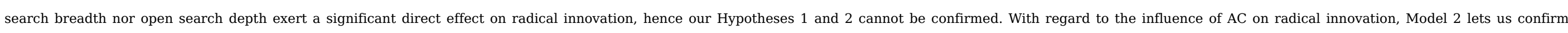

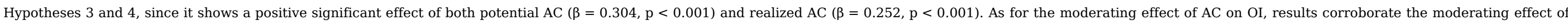

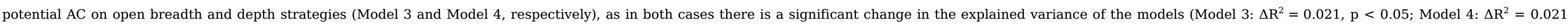

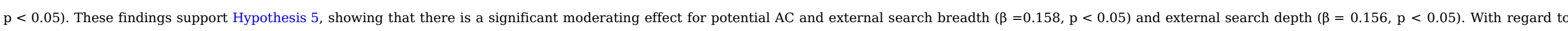




\section{Discussion}

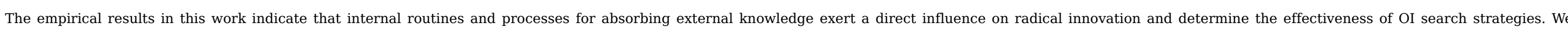

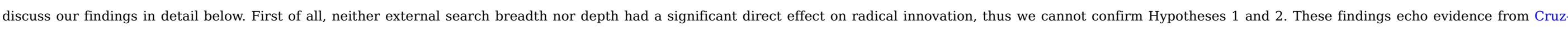

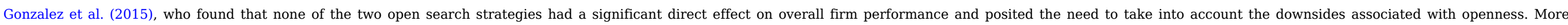

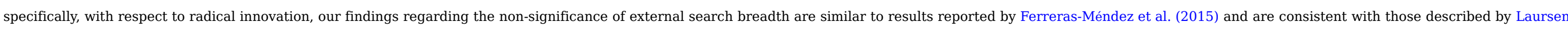

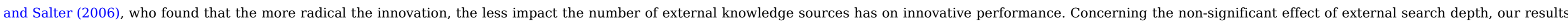

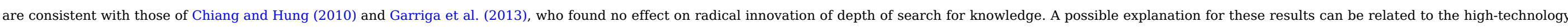

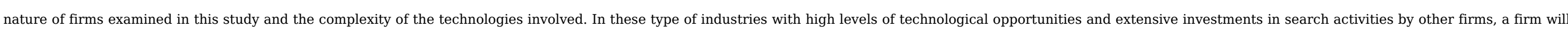

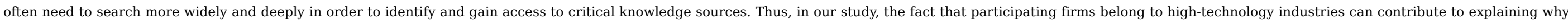

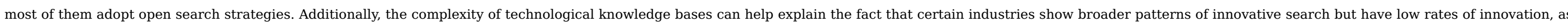

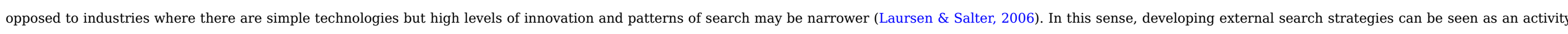
developed by most firms operating in these industries, and a necessary condition to compete in such competitive settings, but it is not a distinctive characteristic when explaining higher radical innovation.

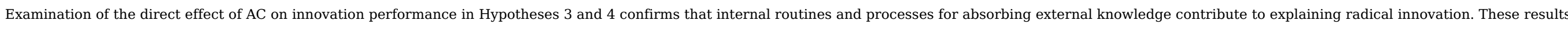

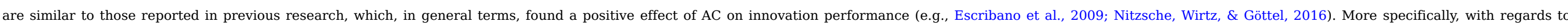

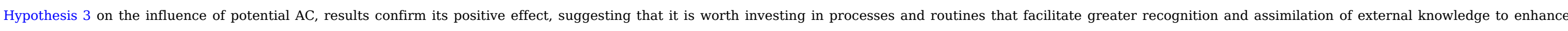

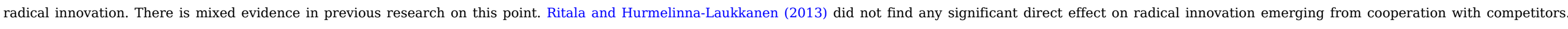

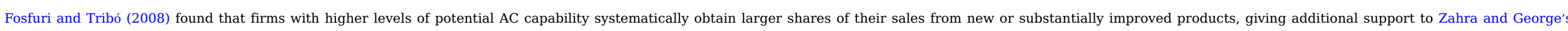

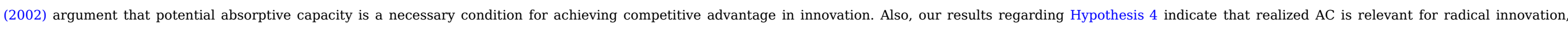

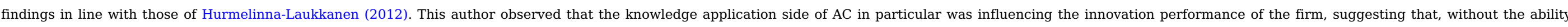

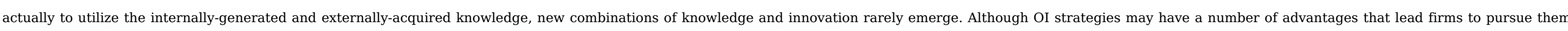

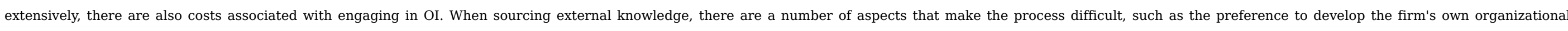

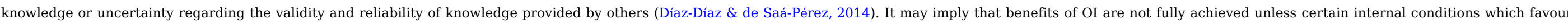

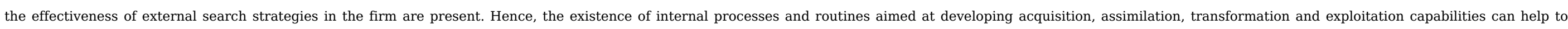

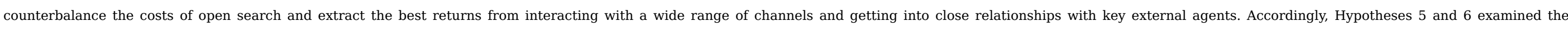

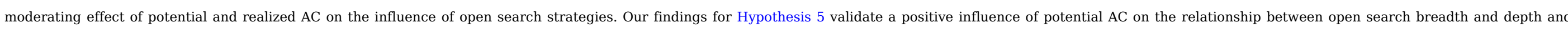

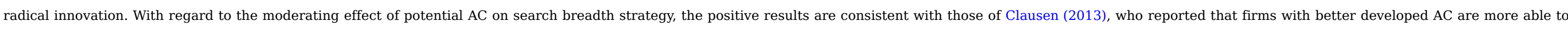

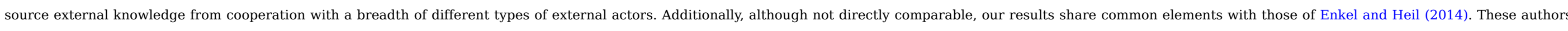

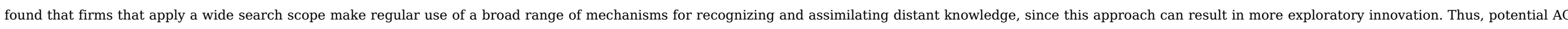

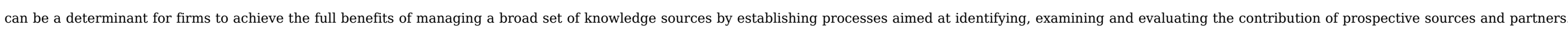

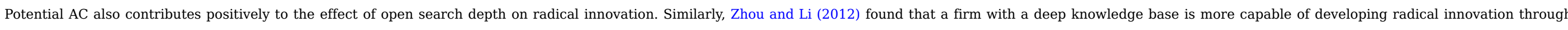

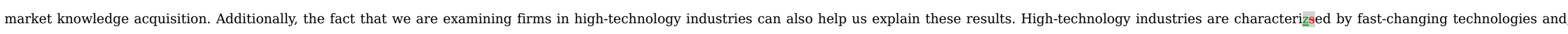

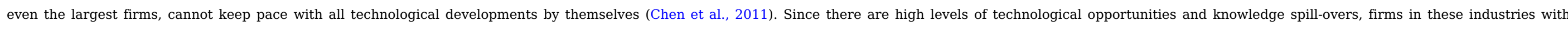
adequate AC capacities to evaluate, assimilate and integrate valuable knowledge from external sources can benefit to a greater extent from a close interaction with external sources.

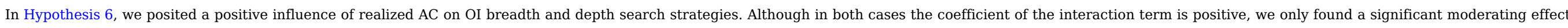




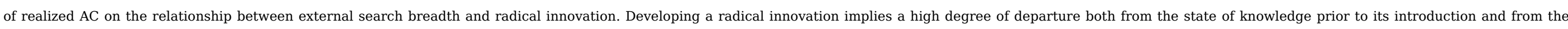

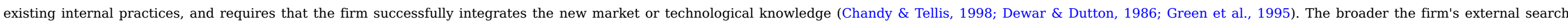

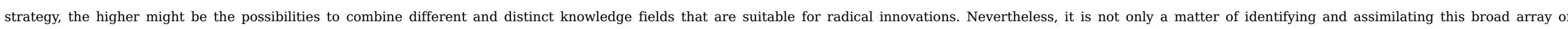

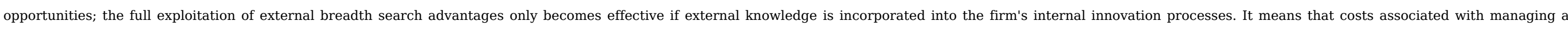

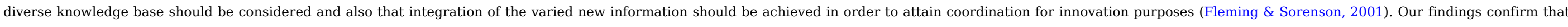

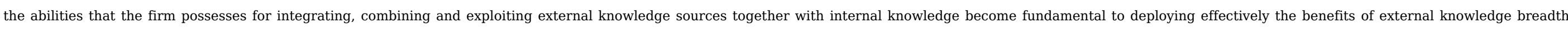

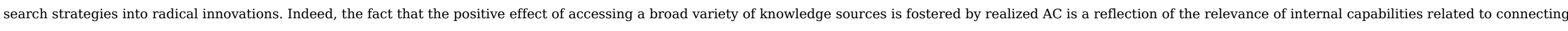

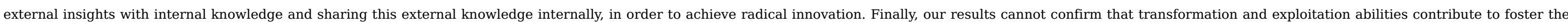

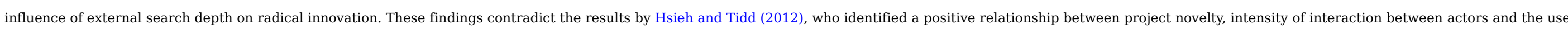

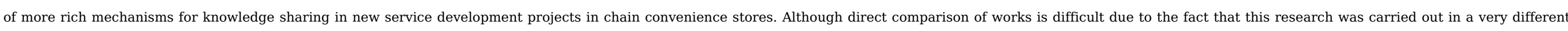

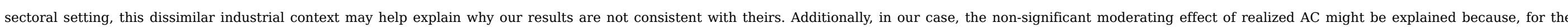

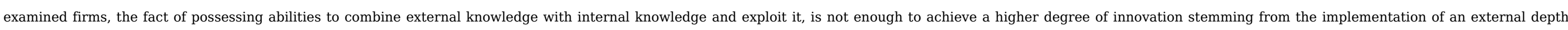

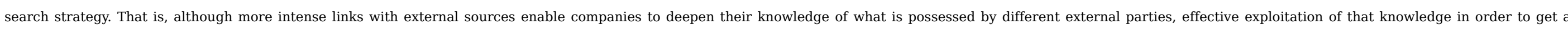

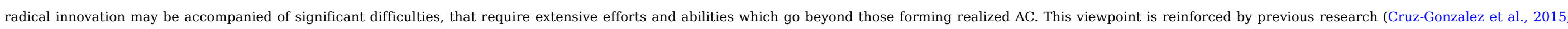

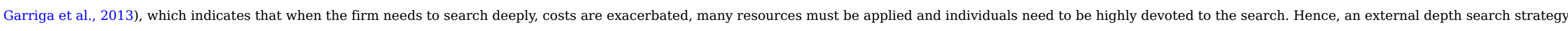

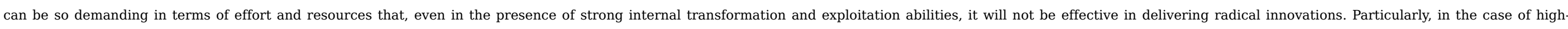

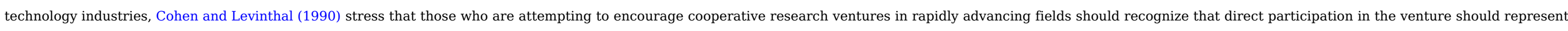

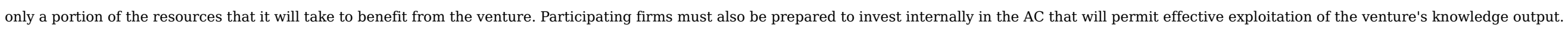

\section{Conclusions}

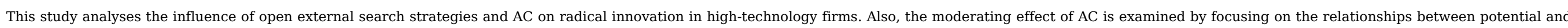
realized AC and external breadth and depth strategies.

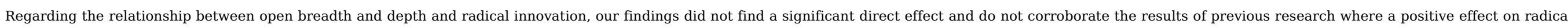

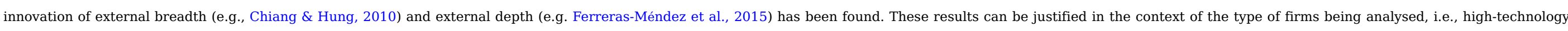

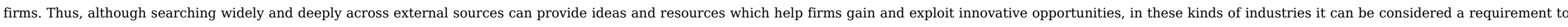

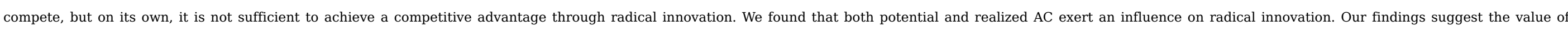

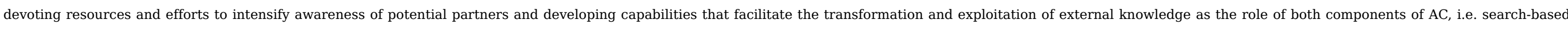

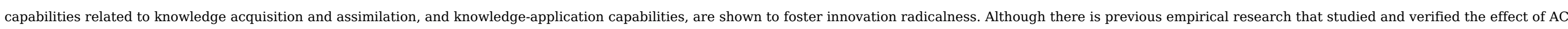

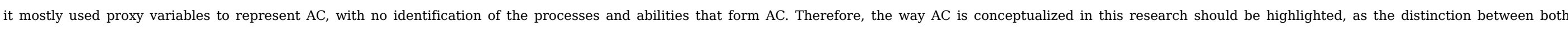
components of AC, based on Zahra and George's (2002), allows a deeper understanding of the role of AC.

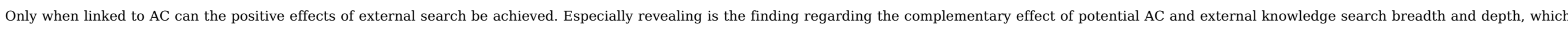

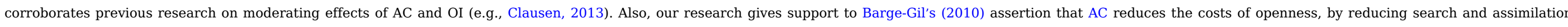

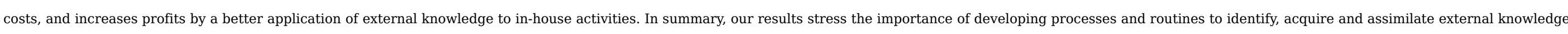

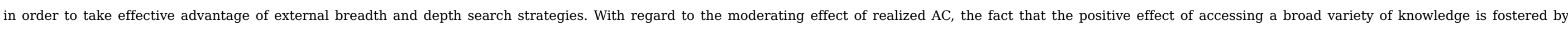

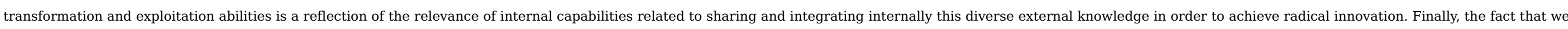

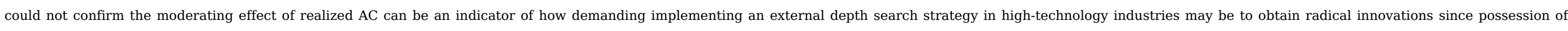
abilities to combine external knowledge with internal knowledge and exploit it is not enough to render a positive result. 


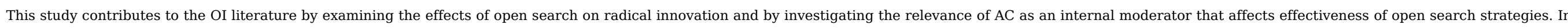

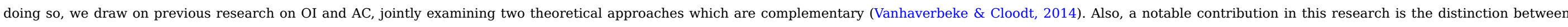

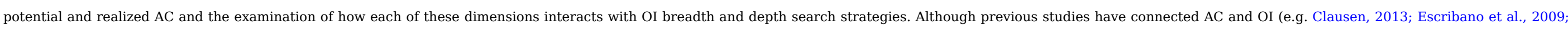

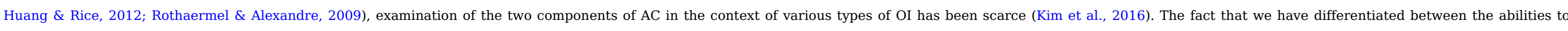

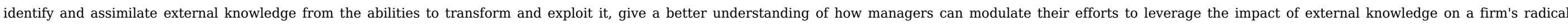
innovation.

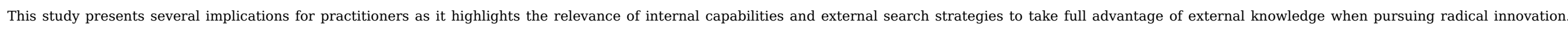

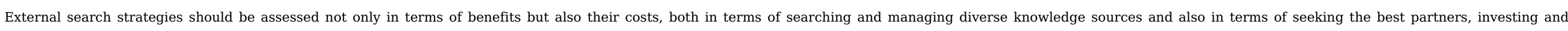

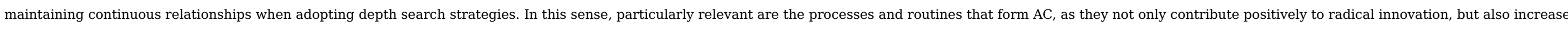

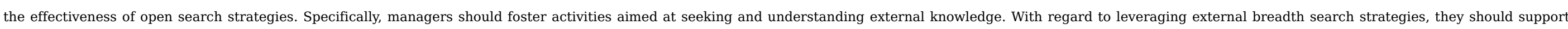

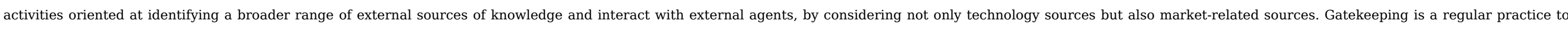

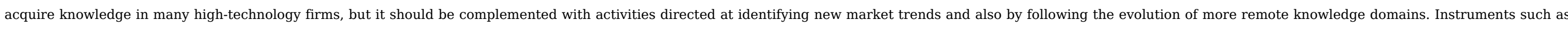

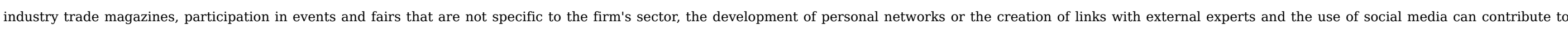

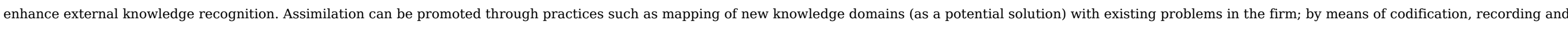

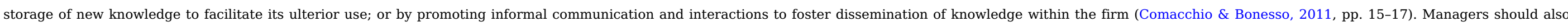

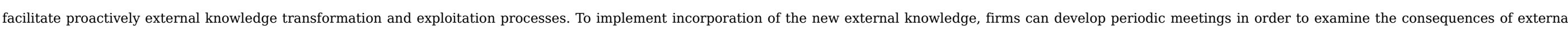

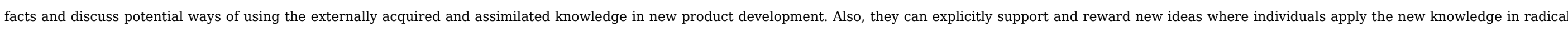

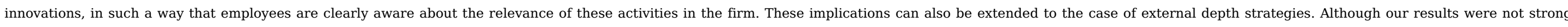

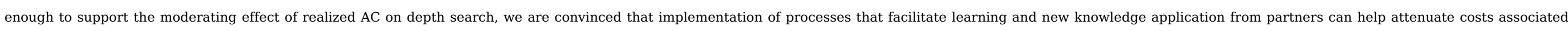
with the development of stable patterns of collaboration.

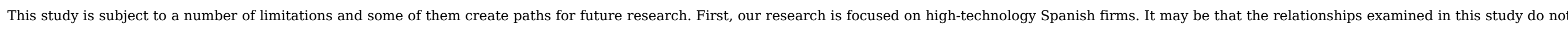

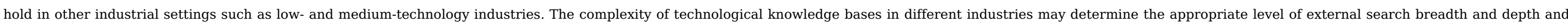

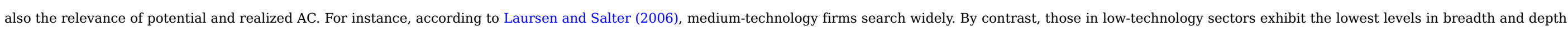

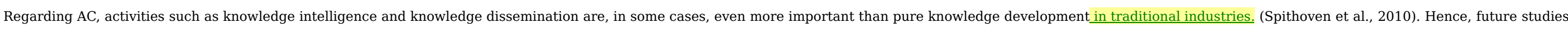

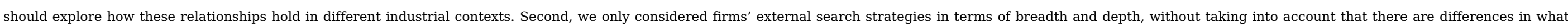

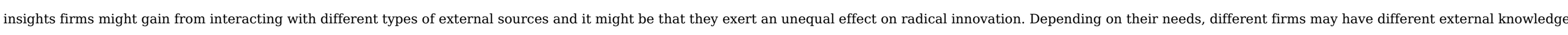

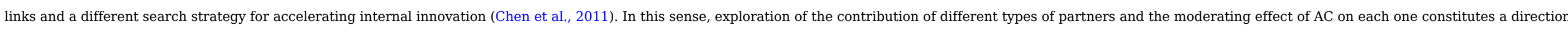

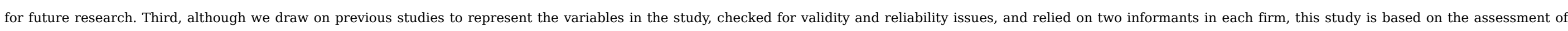
managers, so there is a risk of potential subjective bias. Development of more refined scales and, specially, inclusion of objective data when possible, could help overcome this limitation.

\section{Uncited references}

Fornell and Larcker, 1981.

\section{Acknowledgments}

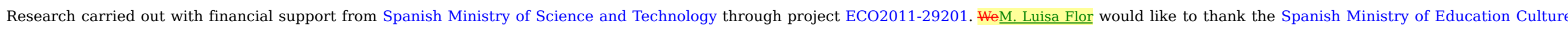
and Sport for its financial support within the framework of its International Mobility Program for Senior Researchers "Salvador de Madariaga" (Reference PRX16-00476).

\section{References}


Ahire S.L., Golhar D.Y. and Waller M.A., Development and validation of TQM implementation constructs, Decision Sciences 1, 1996, 23-56.

Bagozzi R.P. and Phillips L.W., Representing and testing organizational theories: A holistic construal, Administrative Science Quarterly 27, 1982, 459-489.

Barge-Gil A., Open, semi-open and closed innovators: Towards an explanation of degree of openness, Industry and Innovation 17 (6), $2010,577-607$.

Bentler P.M. and Bonett D.G., Significance tests and goodness of fit in the analysis of covariance structures, Psychological Bulletin 88, 1980, 588-606.

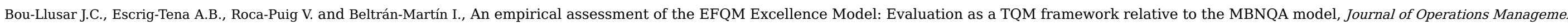

27, 2009, 1-22.

Chandy R. and Tellis G., Organizing for radical product innovation: The overlooked role of willingness to cannibalize, Journal of Marketing Research 35 (4), $1998,474-487$.

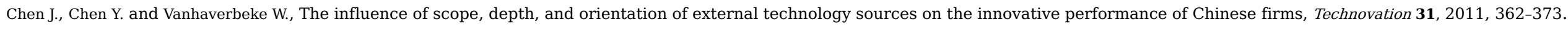

Chesbrough H., Open innovation, the new imperative for creating and profiting from technology, 2003, Harvard Business School Press; Boston, MA.

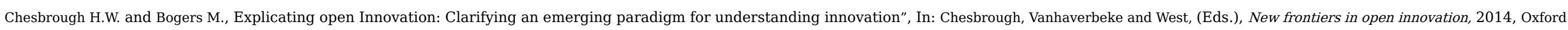

University Press, 3-28.

Chesbrough H. and Brunswicker S., A fad or a phenomenon?: the adoption of open innovation practices in large firms, Research-technology Management 57 (2), $2014,16-25$.

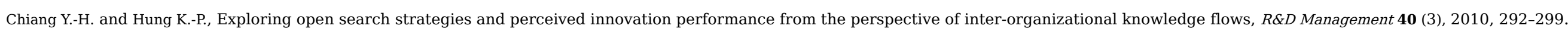

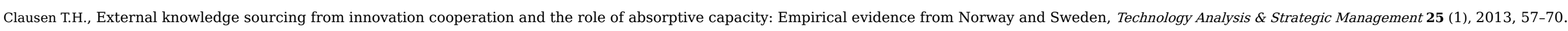

Cohen W. and Levinthal D., Absorptive capacity: A new perspective on learning and innovation, Administrative Science Quarterly 35, $1990,128-152$.

Comacchio A. and Bonesso S., How do firms enact absorptive capacity? A routine based approach, Paper presented at Druid Conference 2011 , Copenhagen, June2011.

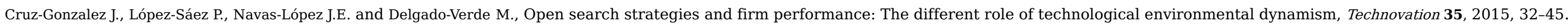

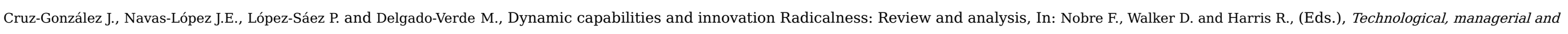

organizational core Competencies: Dynamic innovation and sustainable development, 2012, Business Science; Hershey, PA, 384-406.

Dahlander L. and Gann D.M., How open is innovation?, Research Policy 39, 2010, 699-709.

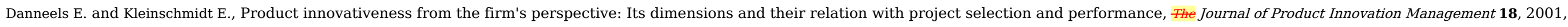

357-373.

Dewar R.D. and Dutton J.E., The adoption of radical and incremental innovations: An empirical analysis, Management Science 32, 1986, $1422-1433$.

Díaz-Díaz N. and de Saá-Pérez P., The interaction between external and internal knowledge sources: An open innovation view, Journal of Knowledge Management 18, 2014 , 430-446.

Enkel E. and Heil S., Preparing for distant collaboration: Antecedents to potential absorptive capacity in cross-industry innovation, Technovation 34, 2014, 242-260.

Escribano A., Fosfuri A. and Tribó J.A., Managing external knowledge flows: The moderating role of absorptive capacity, Research Policy 38, 2009 , 96-105.

Ettlie J., Bridges W. and O'Keefe R., Organization strategy and structural differences for radical versus incremental innovation, Management Science 30, $1984,682-695$.

Fabrizio K.R., Absorptive capacity and the search for innovation, Research Policy 38 (2), 2009, 255-267.

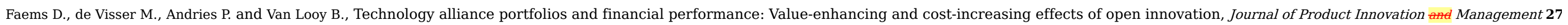

(6), 2010, 785-796. 
Ferreras-Méndez J.L., Fernández-Mesa A. and Alegre J., The relationship between knowledge search strategies and absorptive capacity: A deeper look, Technovation 54, 2016, 48-61.

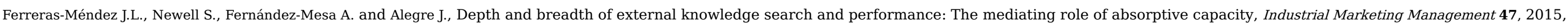
86-97.

Fleming L. and Sorenson O., Technology as a complex adaptive system: Evidence from patent data, Research Policy 30, 2001, 1019-1039.

Fornell C. and Lareker D.F., Evaluating structural equation models with unobservable variables and measurement error, Journal of Aarketing Researeh 18 (1), 1981 , 39 - 50 -

Fosfuri A. and Tribó J.A., Exploring the antecedents of potential absorptive capacity and its impact on innovation performance, Omega 36, 2008, 173-187.

Garriga H., von Krogh G. and Spaeth S., How constraints and knowledge impact open innovation, Strategic Management Journal 36, $2013,1134-1144$.

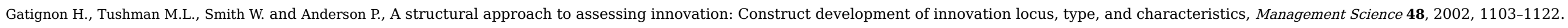
Ghisetti C., Marzucchi A. and Montresor S., The open eco-innovation mode. An empirical investigation of eleven European countries, Research Policy 44 (5), $2015,1080-1093$.

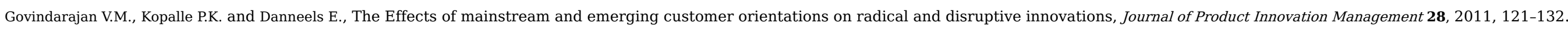

Green S., Gavin M. and Aiman-Smith L., Assessing a multidimensional measure of radical technological innovation, IEEE Transactions of Engineering Management 32, 1995, 203-214.

Hargadon A. and Sutton R., Technology brokering and innovation in a product development firm, Administrative Science Quarterly 42, 1997, 716-749.

Henderson R. and Clark K., Architectural innovation: The reconfiguration of existing product technologies and the failure of established firms, Administrative Science Quarterly 35 (1), $1990,9-30$.

Hsieh K. and Tidd J., Open versus closed new service development: The influences of project novelty, Technovation 32, 2012, 600-608.

Huang F. and Rice P., Openness in product and process innovation, International Journal of Innovation Management 1616 (4), $2012,1250020$.

Huizingh E.K.R.E., Open innovation: State of the art and future perspectives, Technovation 31, 2011, 2-9.

Hurmelinna-Laukkanen P., Constituents and outcomes of absorptive capacity -appropriability regime changing the game, Management Decision 50, 2012, $1178-1199$.

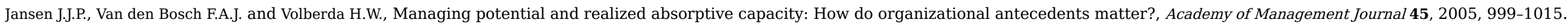

Katila R. and Ahuja G., Something old, something new: A longitudinal study of search behavior and new product introduction, Academy of Management Journal 45 (8), 2002, 1183-1194.

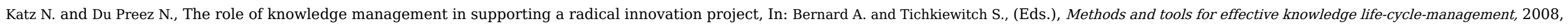

Springer; Amsterdam, the Netherlands, 331-346.

Kim L., Crisis construction and organizational learning: Capability building in catching-up at Hyunday Motor, Organization Science 7, 1998, 502-518.

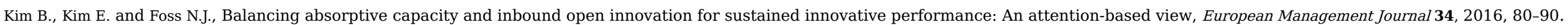

Kogut B. and Zander U., Knowledge of the firm, combinative capabilities and the replication of technology, Organization Science 3, $1992,383-397$.

Lane P.J., Koka B. and Pathak S., The reification of absorptive capacity: A critical review and rejuvenation of the construct, Academy of Management Review 31, $2006,833-863$.

Laursen K. and Salter A., Open for innovation: The role of openness in explaining innovation performance among UK manufacturing firms, Strategic Management Journal 27 (2), 2006, 131-150.

Leiponen A.A. and Helfat C.E., Innovation objectives, knowledge sources, and the benefits of breadth, Strategic Management Journal 31, 2010, 224-236.

Lewin A.Y., Massini S. and Peeters C., Microfoundations of internal and external absorptive capacity routines, Organization Science 22 (1), $2011,81-98$.

Nitzsche P., Wirtz B.W. and Göttel V., Innovation success in the context of inbound open innovation, International Journal of Innovation Management 20 (2), $2016,1650025$. 
Nooteboom B., Vanhaverbeke W., Duysters G., Gilsing V. and van den Oord A., Optimal cognitive distance and absorptive capacity, Research Policy 36, 2007 , $1016-1034$.

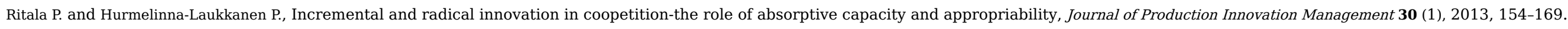
Rothaermel F.T. and Alexandre M.T., Ambidexterity in technology sourcing: The moderating role of absorptive capacity, Management Science 20, 2009, 759-780.

Sainio L., Ritala P. and Hurmelinna-Laukkanen P., Constituents of radical innovation-exploring the role of strategic orientations and market uncertainty, Technovation 32, 2012, 591-599.

Satorra A. and Bentler P.M., A scaled difference chi-square test statistic for moment structure analysis, Psychometrika 66, 2001, 507-514.

Sisodiya S., Johnson J.L. and Grégoire Y., Inbound open innovation for enhanced performance: Enablers and opportunities, Industrial Marketing Management 42, 2013 , 836-849.

Slater S.F. and Narver J.C., Customer-led and market-oriented: Let's not confuse the two, Strategic Management Journal 19, 1998, 1001-1006.

Sofka W. and Grimpe C., Specialized search and innovation performance - evidence across Europe, R\&D Management 30, 2010, 310-323.

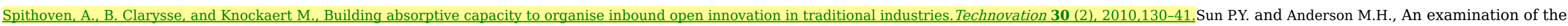
relationship between absorptive capacity and organizational learning, and a proposed integration, International Journal of Management Reviews 12 (2), $2010,130-150$.

Szulansky G., Exploring internal stickiness: Impediments to the transfer of best practice within the firm, Strategic Management Journal 17, $1996,27-43$.

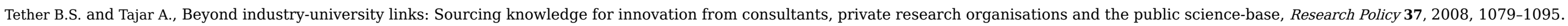

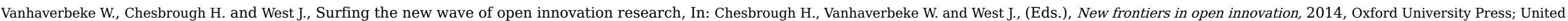
Kingdom, 281-294.

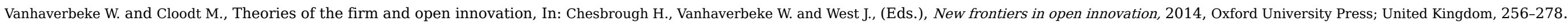

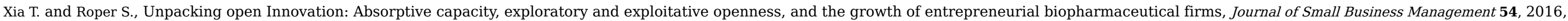
931-952.

Zahra S.A. and George G., Absorptive capacity: A review, reconceptualization, and extension, Academy of Management Review 27, 2002, 185-203.

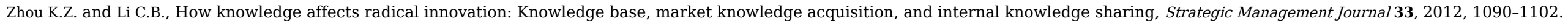

Zhou K.Z., Yim C.K. and Tse D.K., The effects of strategic orientations on technology- and market-based breakthrough innovations, Journal of Marketing 69 (2), 2005 , 42-60.

Zollo M., Reuer J.J. and Singh H., Interorganizational routines and performance in strategic alliances, Organization Science 13 (6), $2002,701-713$.

\section{Queries and Answers}

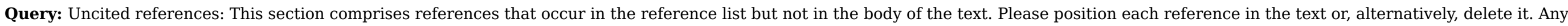
reference not dealt with will be retained in this section. Thank you.

Answer: the reference has been deleted. Thank you four alerting about it.

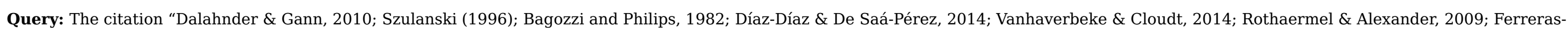
Méndes et al., 2016; Cruz-González et al., 2015” has been changed to match the author name/date in the reference list. Please check.

Answer: Citations have been checked. Everything is correct. Thank you for alerting us about this point.

Query: Refs.Spithoven et al., 2010 is cited in the text but not provided in the reference list. Please provide it in the reference list or delete these citations from the text.

Answer: Thank you. The reference has been added. 